\title{
空気混入水平輸送における 2 次空気の 効果に関する研究 \\ STUDY ON EFFECTS OF SECONDARY AIR INJECTION FOR COMPRESSED AIR TRANSPORT IN HORIZONTAL PIPE
}

\author{
鈴木理仁 $1 \cdot$ 黒沢靖正 $2 \cdot$ 落合実 $3 \cdot$ 遠藤茂勝 4 \\ Yoshihito SUZUKI, Yasumasa KUROSAWA, Minoru OCHIAI and Shigekatsu ENDO
}

\author{
1正会員 工修 千葉県富里町 建設課（广286-0292 千葉県印旙郡富里町七栄652-1） \\ 2正会員 東和建設(侏) 工事部（１02-0031 東京都千代田区飯田橋1-12-5） \\ 3 正会員 工修 日本大学講師 生産工学部土木工学科（广275-8575 千葉県習志野市泉町1-2-1） \\ 4フエロー会員 工博 日本大学教授 生産工学部土木工学科（テ275-8575 千葉県習志野市泉町1-2-1）
}

\begin{abstract}
The purpose of this research is to investigate effect of compressed secondary air injection and flow resistance in horizontal pipe flow transport system by compressed air. This transport system is very useful for high-density slurry transport because it is easily to separating air from slurry. This paper describe about the mechanism of slurry transporting system using a compressed air in the experimentally. In the experiment, the airliquid two-phase flows have been focused on liquid of low viscosity in long distance pipelines with narrow diameter and discussed the effect of secondary air and relation between air-injection volume and friction loss. As the results of experiments it was shown that the secondary air injection is useful for acceleration of slug velocity in horizontal pipe flow.
\end{abstract}

Key Words : multiphase flow, slug flow, horizontal hydraulic transport, secondary air

\section{1.はじめに}

自然環境下で行われる土木構造物の築造に当たつ て, 環境の保全, 維持という問題が重要な課題と なってきた.

特に港湾内で行われる浚渫工事においては浚渫泥 の輸送が従来の方法では環境や生態系に与える影響 が大きいなどの理由で, これまでのポンプ式輸送か ら，圧縮空気を用いた混気輸送方式が採用されるよ うになってきた.

空気輸送技術は, 粉体や粒体を輸送するための技 術として研究が進められていて, 被輸送物の壊れや 管内での摩擦の低減が計れることで, 所要動力が少 なくてすむなどの利点があるため, 粉体輸送の輸送 方法として用いられている. しかし, 粒体や浚渫泥 のように集塊性の低い輸送物は粉体とは異なった流 動となるため, 従来の研究成果をそのまま適用する ことは出来ない。

特に本研究で対象としているような流動性の低い 高濃度スラリー輸送の研究は極めて少ない.しかし 圧縮空気を混入するスラリー輸送でも粉体輸送と同
様に圧力損失の軽減を計れる利点や泥砂と混入空気 との分離が極めて容易であることなど，実用的な面 からのニーズと相まって経験的に行われている.

また, 含水比の高い浚渫泥は粉体や粒体とも異な り, 必要な動力と輸送量の関係 1 つにしても系統的 な研究は極めて少なく, 本質的な輸送メカニズムの 解明を目的とした研究も少ない.

一般には泥砂と圧縮空気をそれぞれ同時連続的に 供給して輸送しているため管路内での輸送様式も極 めて複雑で, 輸送物と空気を交互に送るような方法 を採っていないため, スラグ流となっていると考え られるが，これまで管路内の輸送状況を可視化でき なかったため明確にされていない.

著者らは経験的に行われている現地での浚渫泥の 輸送状況の観察および 2,3 の現地計測の結果と水 と空気を用いた室内での可視化実験結果を検討した 結果，スラグの周期や管内での圧力損失ひ傾向など 流動の様子が現地と室内実験の結果が定性的にかな り良い一致を示していることから, 室内実験によっ て遠距離輸送の課題としての 2 次空気 (Sub air)の 供給による輸送効果を実験的に検討した. 


\section{2. 現地スラリー輸送の特性}

室内実験の実施に先立って現地で行われている浚 渫泥の混気圧送状態を調査し, 室内での水と空気を 用いた実験結果との整合性を調べるためにスラグ流 の基本的な特性であるスラグ流の速度と管内圧力に ついて検討を行った.

現地での輸送実験は概略次のような条件で行われ た.

土砂は海底からの浚渫泥で, 砂, シルト, 粘土等 が混入したもので, 含水比が120〜130程度の黒色の 泥土であった. 浚渫船のスラリーポンプにより管路 に供給され，泥土は同時に供給される圧縮空気によ り順次管路内を5.0〜 10.0m/secのスピードで移動す る. 管路の総延長は $1724.0 \mathrm{~m}$ で, 最初の $114.5 \mathrm{~m}$ 区間 の管径は $\phi=630 \mathrm{~mm}$, 次の $1090.8 \mathrm{~m}$ 区間が $\phi=560 \mathrm{~mm}$, そして残りの $518.7 \mathrm{~m}$ 区間が $\phi=710 \mathrm{~mm}$ で 3 種類の管が 接続されている. 途中 $114.5 \mathrm{~m}$ 区間の一部の高低差は 最大 $3.0 \sim 4.0 \mathrm{~m}$ 程度で浚渫船から $1200 \mathrm{~m}$ 地点で約 135 度ずつ， 2 力所で折れ，全体として，ほぼ 90 度方向 に曲げられていて，そこから 続き, 大気中に放出されるようになっている.

測定中の圧送土砂量は600 $800 \mathrm{~m}^{3} / \mathrm{hr}$ で空気量は 約 $300 \mathrm{~m}^{3} / \mathrm{min}$ であった. 圧力計は浚渫船の圧送地点 と600mまでは $300 \mathrm{~m}$ 毎に，それ以降は $200 \mathrm{~m}$ 間隔で計 8 力所設置されている. スラグの速度は圧力記録と現 場での 2 地点間の通過時間から算出した. また, 2 次空気供給量は管路始点から $1000 \mathrm{~m}$ 地点に設けられ ている.これらの条件で 9 ケース，19通りの土量と 空気量の組み合わせについて実験を行った結果, 次 のことが明らかとなった.

(1) 圧送土量の供給量を変化させてもスラグ速 度は変らず，ほぼ一定の速度で移動し, 土 量の増加に伴いスラグ流の発生周期が短く なる.

（2） スラグ流の速度は空気量にのみ支配され， 空気量が増大するとスラグ流の速度も増大 する.

（3）元空気 (Main air)の他に管路の途中から 2 次空気 (Sub air) を供給する場合のスラグ流 速度は 2 次空気量の増加と共に増す。

（4）元空気量を一定として圧送土砂量を増加さ せるとスラグ流発生地点付近の管内圧力は 増大する.

以上の結果は泥上の代わりに水已空気を用いて行っ た著者らのスラグ流に関する実験結果とほぼ同様な 結果を示し, 定性的な傾向がきわめてよく一致する ことから管路途中からの 2 次空気の供給によるスラ グ流の流動メカニズムの変化や輸送効率について室 内実験結果より検討するもので, 物性の著しく異な る実験結果を比較検討することによりスラグ流の流 動メカニズムや長距離輸送の可能性について検討し ようとするものである.

\section{3．実験内容および方法}

ここではスラグ流のモデルとして可視化を前提と した水と空気により再現するもので，スラグ流の速 度や各種条件下における圧力損失などを検討するも のである.

実験には内径 $3.8 \mathrm{~cm}$ のビニールパイプを用い, 総 延長を $150.0 \mathrm{~m}$ と, 途中の $65.0 \mathrm{~m}$ 地点から 2 次空気 を導入したときのスラグ流の運動特性がどのように 変化するかを検討することを目的とした.

実験装置の概略は図-1に示すとおりである．全長 $150.0 \mathrm{~m}$ の゙ニールパイプで管路を設け, 途中の 5 カ 所に圧力測定のための圧力計を設置した. それぞれ の距離は水の供給口を基点とした $1.0 \mathrm{~m}, 20.0 \mathrm{~m}$, $60.0 \mathrm{~m} ， 70.0 \mathrm{~m}$ およ゙ $130.0 \mathrm{~m}$ 各地点である. またス

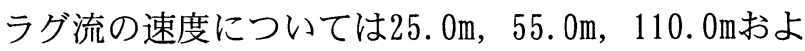
び130.0m地点からそれぞれ $10.0 \mathrm{~m}$ 区間の移動時間を 目視観測より求めた.

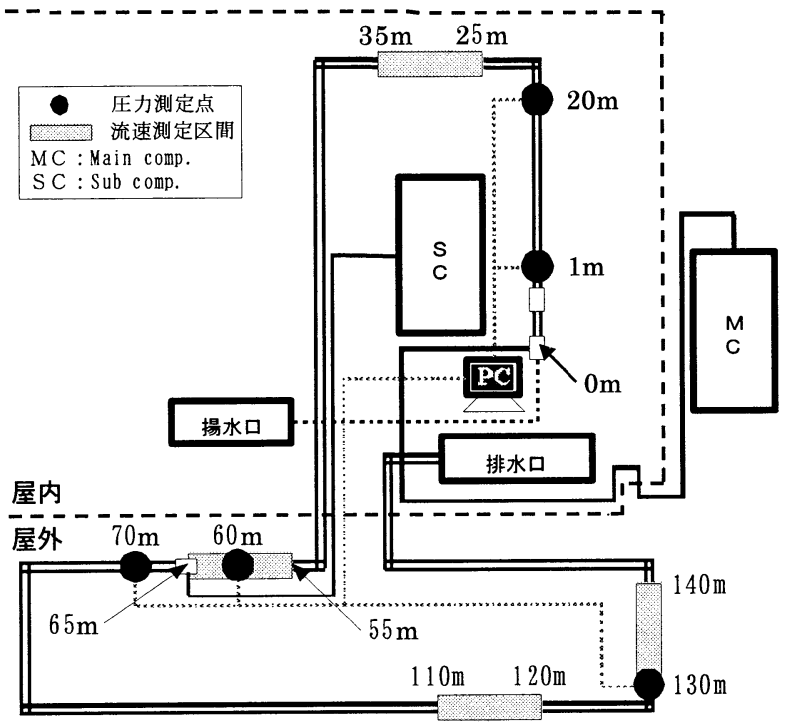

図-1 実験装置概略図

空気量や水量についてはローター式流量計および 電磁式流量計を通して供給されるようになっている. そして圧力測定にはダイヤグラム式の圧力センサー 許容圧力 $5 \mathrm{kgf} / \mathrm{cm}^{2}(0.49 \mathrm{MPa})$ のものを用いた.

実験条件は供給水量 $\mathrm{Q}_{\omega}$ を一定 $\left(\mathrm{Q}_{\omega}=16.5 \mathrm{l} / \mathrm{min}\right)$ と して, 元空気量 $Q_{\mathrm{ma}}$ を $65.0,80.0,100.0$ および $120.0 \mathrm{l} / \mathrm{min}$ とし, それぞれの $\mathrm{Q}_{\mathrm{ma}}$ に対して 2 次空気 量 $\mathrm{Q}_{\mathrm{s}}$ を $0.0,20.0 ， 40.0 ， 60.0 ， 80.0$ および 100.0 $1 / \mathrm{min}$ 変化させた組み合わせの条件を基本とし, この他に $\mathrm{Q}_{\mathrm{ma}}$ と $\mathrm{Q}_{\omega}$ を変化させた組み合わせなどを含 め, 合計44通りの条件で実験を行った.

\section{4. 結果と考察}

水と空気を用いた実験結果と現地のスラリー輸送 の計測結果との整合性についてはおおむね確認され, 定性的な傾向はきわめてよく一致することが明らか 
となっている.

一方，著者らの実験によって空気と輸送物を連続 的に管路内に供給するとプラグ流にはならずスラグ 流になること，また浚渫土砂などを輸送の対象とす る場合ではプラグ輸送では管路内の摩擦損失が大き くなり，輸送速度や距離を考えると輸送効率の面で あまり期待できないと考えられる.

水・空気を用いたスラグ流に関する基礎的な実験 の結果，スラグ流が発生する地点は条件に関わらず ほぼ一定し，その時の管内水位は管径の約 $70 \%$ 前後 となる。 そしてスラグ流の速度は空気量に支配され て，空気量の増大と共に増大する。 また空気量を一 定とした場合，水の量を増加させるとスラグ流の発 生頻度は多くなるがスラグ流の速度は変わらないな ぞの基本的な特性が明らかとなっている。 そこで, 2 次空気を供給した時のこれらの特性について次に 検討する.

\section{（1）スラグ流の周期分布}

ここでは 2 次空気の供給によるスラグ流の変化を 調べることを主目的としているので，まずスラグ流 の分布について検討する.

2 次空気の供給地点は水の供給地点より $65.0 \mathrm{~m}$ 地 点なので，供給空気の影響を受けにくいと考えられ る25.0m地点で測定したスラグ流の周期分布につい て検討する. 図-2(a), (b)は $Q_{\omega}=16.5 \mathrm{l} / \mathrm{min}, Q_{\mathrm{ma}}$ $=80.0 \mathrm{l} / \mathrm{min}$ で (a) の方が $\mathrm{Q}_{\mathrm{sa}}=0.0 \mathrm{l} / \mathrm{min}$ で 2 次空気 がない場合で，（b）の方は $\mathrm{Q}_{\mathrm{sa}}=40.0 \mathrm{l} / \mathrm{min}$ の場合で ある．両者の頻度分布はほとんど変わらず同様な結

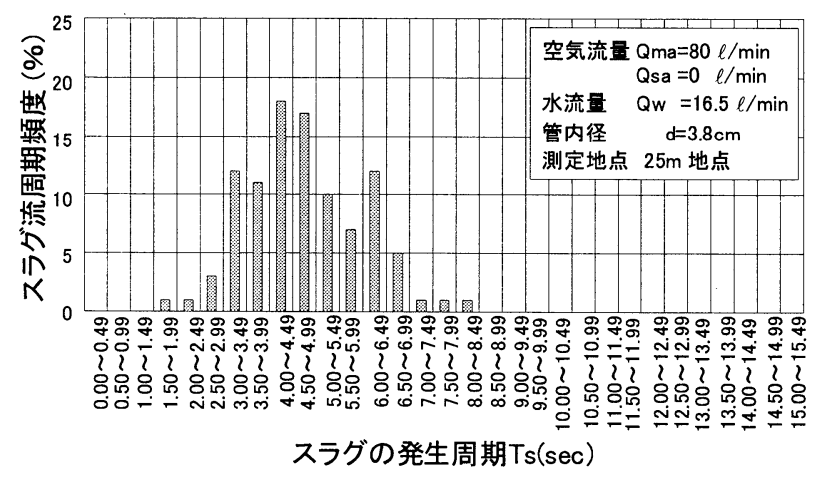

図-2(a) スラグ流周期頻度分布

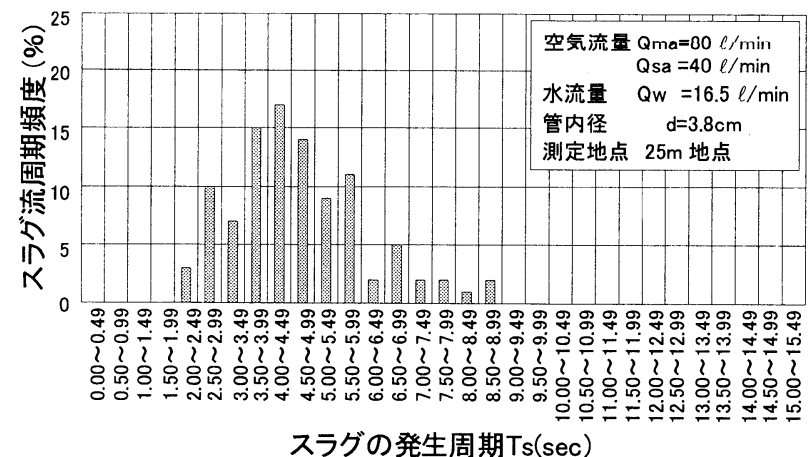

図-2(b) スラグ流周期頻度分布

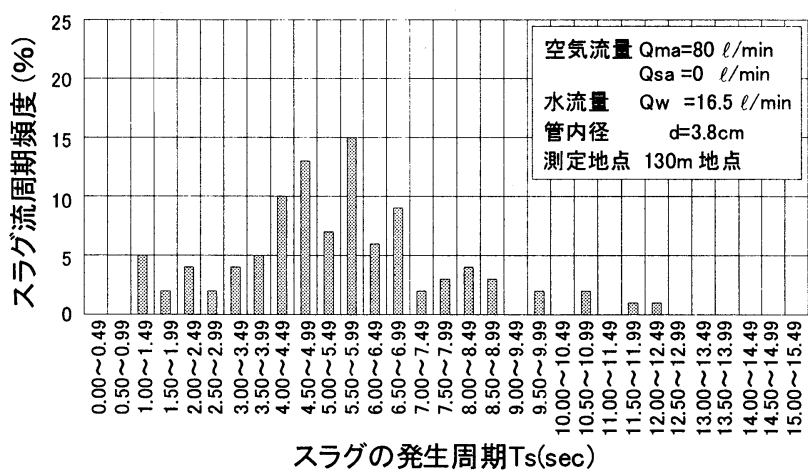

図-3(a) スラグ流周期頻度分布

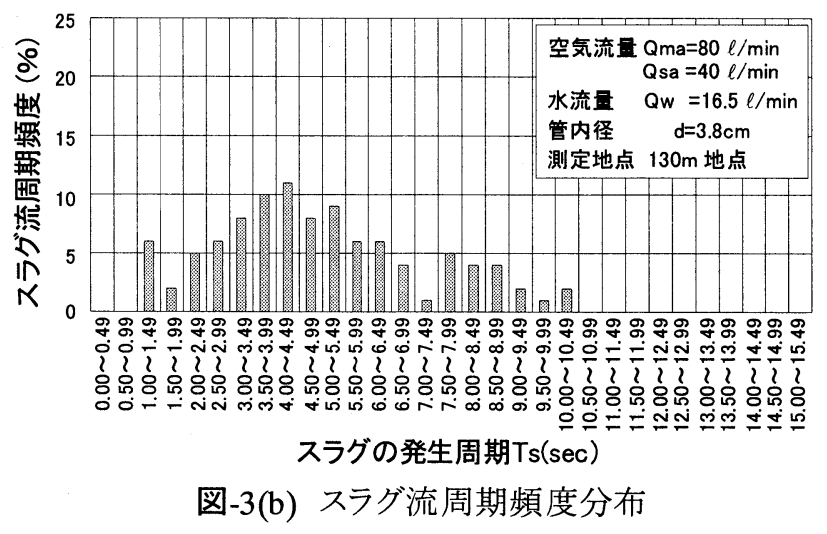

果を示している。これは 2 次空気の供給口より 40. $0 \mathrm{~m}$ 遡った地点であることから，スラグ流の発 生や運動に対しても 2 次空気の影響はほとんど認め られないためと考えられる. しかし，全く同じ条件 の130.0m地点のスラグ流の周期分布を示したものが 図-3(a)，(b)である。これらの結果はそれぞれ図-2(a), (b)に対応するもので，(a) は 2 次空気が無い場合で $\mathrm{Q}_{\mathrm{sa}}=0.0 \mathrm{l} / \mathrm{min}$ また (b) は $\mathrm{Q}_{\mathrm{sa}}=40.0 \mathrm{l} / \mathrm{min}$ 場合で あるが 2 次空気の供給地点より後の所であるため周 期分布そのものが図-2(a)，(b)とは異なっている．ま た図-3(a) は 2 次空気が無いが図-3(b) は $Q_{\mathrm{sa}}=40.0$ $1 / \mathrm{min}$ 場合であるため 2 次空気の影響を受けてい ることがわかる. 図-3(a)の方が図-3(b)に比べて分布 がやや乱れているのはこの地点まで到達するまでの 圧力損失の影響と考えられる.また図-3(b)の方は 2 次空気の供給により新たな運動が始まったため分布 が整えられたためと考えられる。

\section{（2） 2 次空気量とスラグ流発生周期}

2 次空気供給地点前後の各 2 地点における 2 次空 気量によるスラグ流周期への影響をまとめたものが 図-4である. 図-4は横軸に 2 次空気量 $Q_{\mathrm{s}}$ を取り, 縦軸にそれぞれ $\mathrm{Q}_{\mathrm{sa}}$ に対する各地点でのスラグ流平 均周期のばらつきを示したものである.

これらによれば $\mathrm{Q}_{\mathrm{s}}=40.0 \mathrm{l} / \mathrm{min} の$ 時は $\mathrm{Q}_{\mathrm{sa}}=0.0$ l/minの時と同様に周期のバラツキは少ないが, $Q_{\mathrm{sa}}$ $=20.0,60.0,80.0,100.0 \mathrm{l} / \mathrm{min}$ では各地点による スラグ平均周期のバラツキが大きく，2 次空気量の 供給量によってはスラグ流の周期を乱す結果となり， 規則正しいスラグ流が形成されなくなり, 輸送効率 
を低下させる可能性があると考えられる.

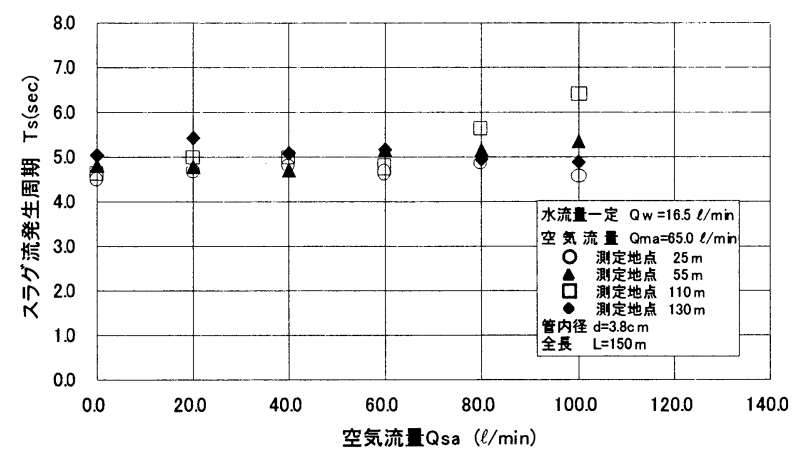

図-4 スラグ流の平均周期(水流量一定)

\section{（3）管内平均压力特性}

2 次空気の供給がない場合の管内の圧力変化特性 を示したものが図-5である.この図は水流量を $\mathrm{Q}_{\omega}$ $=16.5 \mathrm{l} / \mathrm{min}$ で一定とした場合で, 横軸に管路の距 離を取り，縦軸にはそれぞれの地点の圧力を示した もので, 元空気を変化させた場合の結果をまとめて 示してある.

一般に管内圧力はスラグが通過する前後で著しく 変化する. またスラグ速度は後で述べるように 2.0 $\sim 5.0 \mathrm{~m} / \mathrm{sec}$ にまで達し, 管内部の時間的な圧力変動 が極めて早いことやスラグ流の内部に多数の気泡を 巻き込んでいるため, 圧力時系列は極めて複雑な履 歴を示している. そのためここでは, スラグ流の通 過時の管内圧力として，2.0Hzで測定した結果を降 べき順にした時の上位 $1 / 10$ の平均圧力で示した. 図 中の白丸印は $\mathrm{Q}_{\mathrm{ma}}=65.0 \mathrm{l} / \mathrm{min}$ で最も空気量の少ない 場合であるが遠方に進むに従って管内圧力は低下し， 圧力損失が生じることを示していて，10.0m地点と 130.0m地点間での圧力は緩やかに減少し, およそ半 分程度にまで減少することがわかる.

これらの傾向は元空気量が序々に増大する場合で もほぼ同様な圧力低下の傾向を示しているが元空気 量が増大すると管内圧力が徐々に増し, 圧力勾配も 幾分大きくなる傾向にある.

次に示した図-6の結果は $\mathrm{Q}_{\mathrm{ma}}=65.01 / \mathrm{min}, \mathrm{Q}_{\omega}$ $=16.5 \mathrm{l} / \mathrm{min}$ とし, 2 次空気量 $Q_{s a}$ を導入し, 徐々に 増加させた時の管内の圧力変化特性を示したもので ある. 縦軸, 横軸は図-4 と同じであるが圧力変化の 割合が 2 次空気の供給口より上流側がやや全体的に フラットになっている傾向を除けば, 元空気を増大 させたときの傾向とほぼ一致し， 2 次空気を導入す ることにより, 元空気量を増加させたと同じ効果が 現れ, 全ての地点で 2 次空気の増大と共に管内圧力 は上昇する傾向にあるが, $1.0 \mathrm{~m}$ 地点と $130.0 \mathrm{~m}$ 地点の 圧力差は元空気を増大させた場合の結果と同様に約 1/2程度まで減少していることがわかる.

次の図-7の結果は供給水量を $\mathrm{Q}_{\omega}=16.5 \mathrm{l} / \mathrm{min}$ で一 定とし, 元空気量と 2 次空気量の合計, すなわち $\mathrm{Q}_{\mathrm{m}}$ ${ }_{\mathrm{a}}+\mathrm{Q}_{\mathrm{sa}}=120.0 \mathrm{l} / \mathrm{min}$ で一定とした時の管内の圧力変 化特性を示したものである.この結果では 2 次空気
の供給地点 $65.0 \mathrm{~m}$ より流側では元空気の流量差に よる圧力差がやや認められるが，2 次空気の供給地 点より下流側での管内の圧力差は全ての条件に対し て極めて少なく，ほぼ同様な值となっている．すな わち図-5，6，7の傾向から認められるように元空気 や 2 次空気量に関わらず管内の圧力は $\mathrm{Q}_{\mathrm{ma}}$ と $\mathrm{Q}_{\mathrm{s}}$ の total空気量に支配されて増加し, 図一7に認められ る様に total空気量が等しければ，管内の圧力変動 特性は等しくなり，2次空気量の供給は元空気量の 増加と同様の効果を有する.

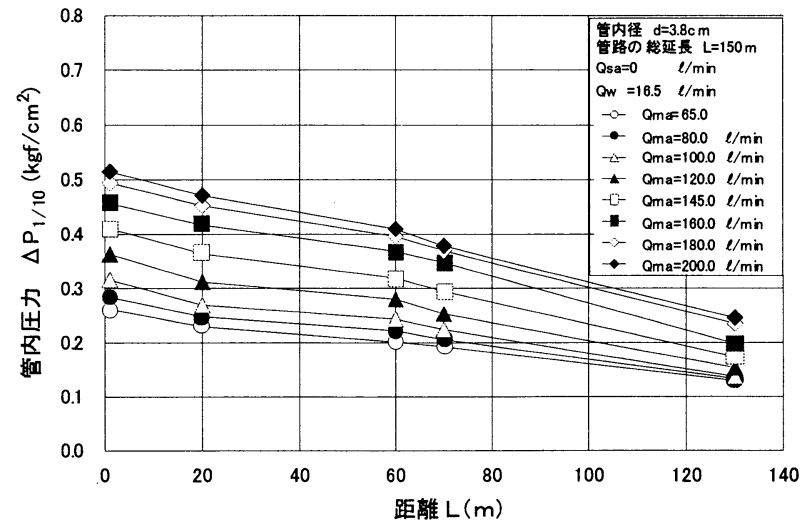

図-5 管内圧力の流れ方向変化

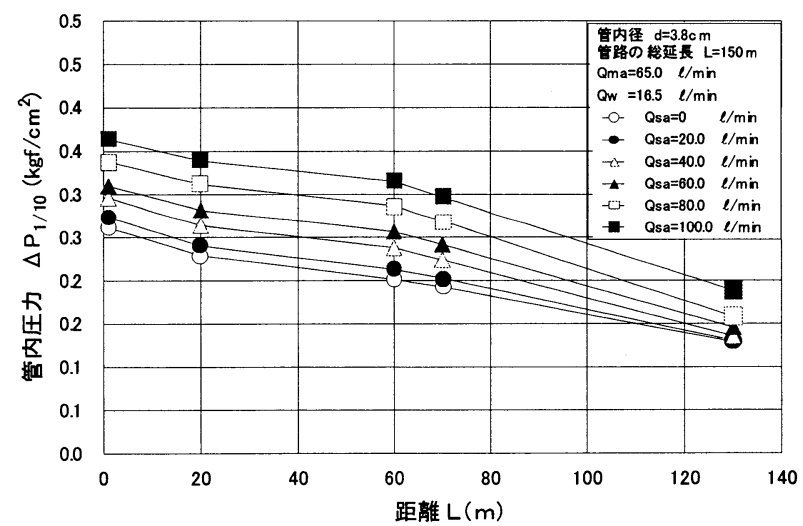

図-6 管内圧力の流れ方向変化

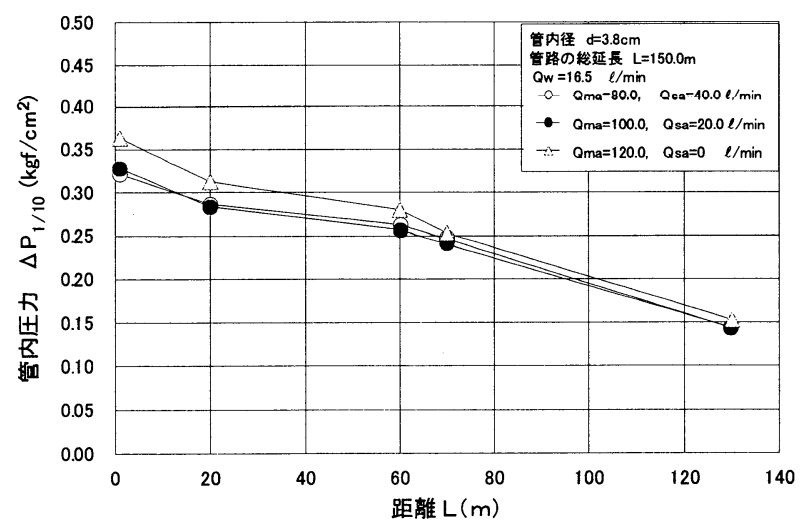

図-7 管内圧力の流れ方向変化

\section{（4） 2 次空気量とスラグ流速度}

スラグ流速度に関する 2 次空気量の効果を調べた ものが図-8である. 図-8は横軸に管路の距離を取り, 縦軸にはそれぞれの地点の前後 $10.0 \mathrm{~m}$ 区間の平均ス 
ラグ速度を取って示したものである. 条件としては, 管内圧力を検討した図-6の条件に対応するもので, $\mathrm{Q}_{\mathrm{ma}}=65.0 \mathrm{l} / \mathrm{min}, \mathrm{Q}_{\omega}=16.5 \mathrm{l} / \mathrm{min}$ とし, 2次空気量 を20.0 1/min毎に増大させた時の各測定地点での平 均スラグ流速度を示したものである.

この結果に示されるように 2 次空気を与えない白 丸印のケースでは $25.0 \mathrm{~m}$ 地点から $140.0 \mathrm{~m}$ 区間の $115.0 \mathrm{~m}$ 区間の平均スラグ流速度は $1.63 \mathrm{~m} / \mathrm{sec}$ で途中

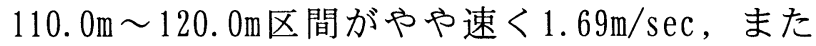
$25.0 \mathrm{~m} \sim 35.0 \mathrm{~m}$ 区間では $1.61 \mathrm{~m} / \mathrm{sec}$ とやや遅い部分も 認められるが平均的にほぼ一定した傾向となってい ることがわかる. しかし，2次空気を元空気の約 30\%ほど供給してやると, 供給口より遠方の地点で 明らかにスラグ速度が増加することがわかる. そし て元空気量とほぼ等しい量の 2 次空気量 $Q_{\mathrm{sa}}=60.0$ 1/minに対するスラグ流の速度は約2倍程度まで増加 し, 元空気量の 1.5 倍程度の空気量 $Q_{s a}=100.0 \mathrm{l} / \mathrm{min}$ の場合でのスラグ流速度は3倍にも達している.

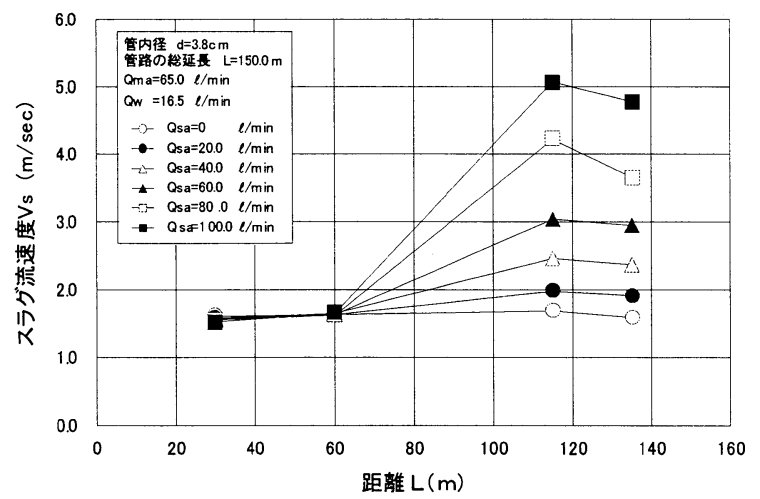

図-8 2次空気によるスラグ流の流れ方向流速変化

このように 2 次空気の供給は管内を走るスラグ流 の速度の増加に著しく寄与するのでスラグ流輸送効 率を増大させるのにきわめて有効な方法であるとい える.このことは遠距離を輸送する場合では元空気 量は少なくても適当な部分から更に 2 次空気を導入 することにより輸送効率を上げることができ，空気 量を分割することで途中の圧力損失を軽減できるこ とを意味している.

\section{（5）2次空気量と速度増加}

スラグ輸送における 2 次空気の導入効果について は前節に述べた通りであるが，2次空気量の増加に よるスラグ流速の増加の割合を示したものが図-9で ある．横軸には 2 次空気の供給量 $\mathrm{Q}_{\mathrm{s}}$ を，また縦軸には スラク流の速度を示したものである.この結果で岏空気量を $\mathrm{Q}_{\mathrm{ma}}=65.0 \mathrm{l} / \mathrm{min} \sim 120.0 \mathrm{l} / \mathrm{min}$ と4段階に変化させ， それぞれのケースについて2次空気量を $Q_{\mathrm{sa}}=20.0$

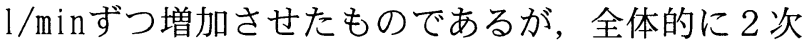
空気量ごとに速度は増加し，その割合は 2 次空気量 が多くなるほど著しくなる傾向にある. しかし，こ の図に見られるように元空気量の差による速度差が 2 次空気量の大小にかかわらずそのまま維持されて おり，管内スラグ流の初期速度は元空気量によって

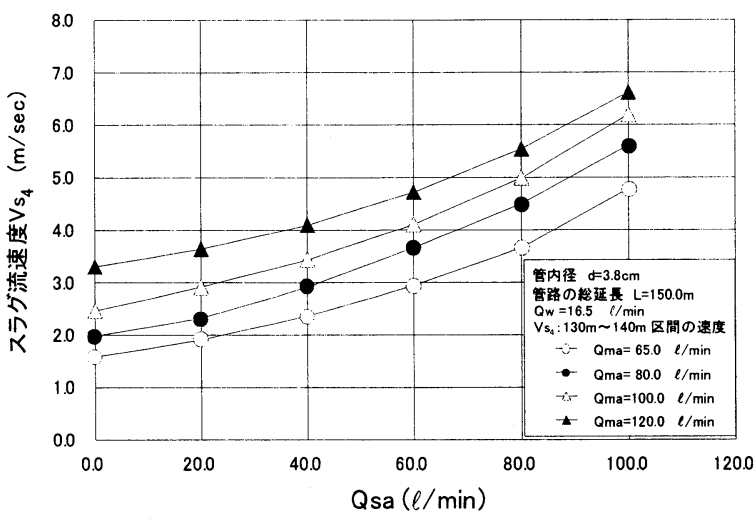

図-9 2次空気量によるスラグ流の速度変化 決まることがわかる. 従って元空気量と 2 次空気量 の両方を組み合わせることによりスラグ流の速度を コントロールできるものと考えられる.

\section{(6) total空気量とスラグ流速度}

スラグ流の速度は 2 次空気の導入によって効果的 に増大することがわかったが，元空気のみの場合や 元空気量と 2 次空気量の組み合わせでtotal空気量 と等しくした場合のスラグ速度の結果をまとめたの が図-10である.この結果は横軸に元空気量 $Q_{m a}$ と 2 次空気量 $Q_{\mathrm{sa}}$ の total空気量 $\mathrm{Q}_{\mathrm{a}}$ と供給水量 $\mathrm{Q}_{\omega}$ の比を取 り, 縦軸には出口直前のフラグ流の速度 $\mathrm{V}_{\text {st }}$ とって 示したものである. それぞれの元空気量に対して 2 次空気を供給した場合の結果をまとめたものである.

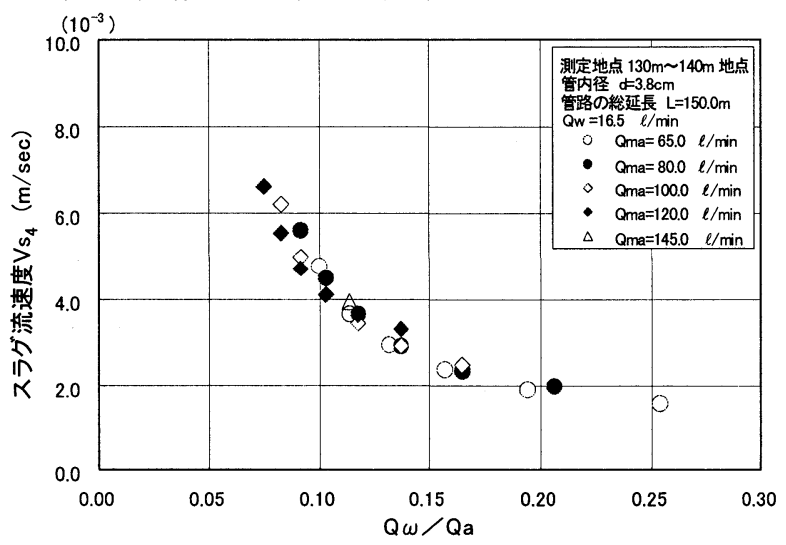

図-10 総空気量とスラグ流速度

この結果の場合では $\mathrm{Q}_{\omega}=16.5 \mathrm{l} / \mathrm{min}$ で一定として いるため, いくつかの記号が重なっている所では total空気量が等しいものである. そのようにして 見ると, 空気量の供給の仕方に関係なく total空気 量が等しければ, 元空気量のみの場合でも元空気量 と 2 次空気量の合計空気量が等しければスラグ流の 管内速度は等しくなることを示していて，スラグ流 の速度は空気の供給の仕方には関係なく, total空 気量に支配されることを示している. 一方空気量が 多くなり, 供給水量が空気量の $10 \%$ 以下になるとス ラグ流の速度にややバラツキが生じる。これは空気 量が著しく多いため基本的には安定したスラグ流が 形成されないことによるもので，むしろ，噴霧流や 環状流といわれる流れになるためと考えられる. 


\section{(7) 輸送管内の圧力損失}

スラグ輸送における管内の圧力損失は所要動力や 空気流量を決める上で重要な要素である. そこで, 本実験における場合の単位管長当たりの圧力損失に ついてまとめたのが次の図-11である。この図は横 軸にスラグ流発生直前の $1.0 \mathrm{~m}$ 地点と管路の出口にほ ぼ近い $130.0 \mathrm{~m}$ 地点との圧力差から求めたものである.

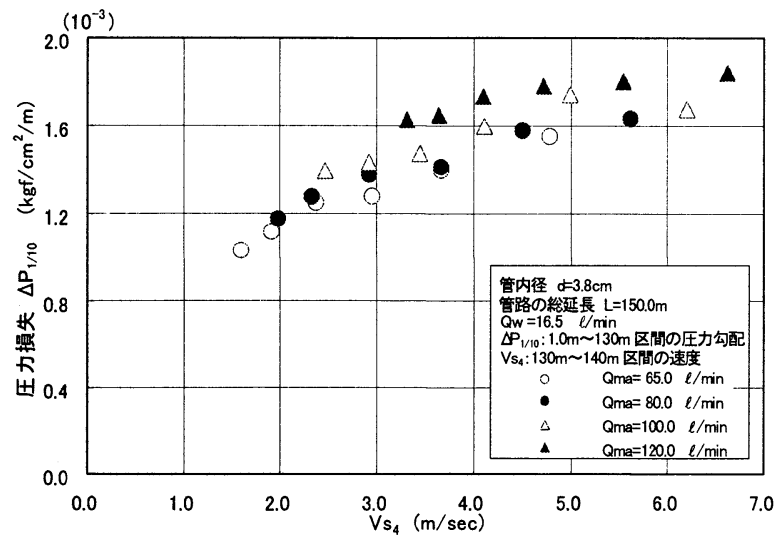

図-11 単位管長あたりの圧力損失

この結果によれば管長の単位長さ当たりの圧力損 失はスラグ管の出口付近の $130.0 \sim 140.0 \mathrm{~m}$ 間の平 均スラグ速度の関係で見るとスラグ速度の増加と共 に単位長さ当たりの圧力損失は増大する傾向にある がやや速度が速い方が圧力損失が少なくなるようで ある.これは空気の小さい気泡が多数スラグ流中に 含まれるためと考えられる.

\section{5. 結論}

本研究により, 水空気を用いたスラグ流に関し 2 次空気を供給したしきのスラグ流の特性のまこめる と以下のようになる.

（1）管内のスラグ流周期の 2 次空気供給地点前後の 頻度分布は 2 次空気量の有無に関わらず基本的 な分布形はほとんど変わらず平均周期もほぼ同 じであるが，供給地点より後の地点の周期分布 は 2 次空気の供給があると変化する.

（2） 2 次空気を供給する場合では供給 2 次空気量に よってはスラグの発生周期に影響を与え，スラ グ周期を乱す結果となることが多いが，ある特 定な空気量の時は 2 次空気を供給しないときと 同様にスラグ周期が乱れず，ほぼ一定となるよ うな空気量が存在すると考えられる.

（3） 2 次空気の供給が無い場合の距離による圧力降 下の割合は約 $130.0 \mathrm{~m}$ 区間では比較的緩やかで, ほぼ一次元的に降下していく. しかしこの傾向 も元空気量が大きくなると圧力降下の割合が著 しくなり, 空気量が多いほど圧力損失が増大す る傾向にある。

（4）元空気量を一定として 2 次空気を供給した時の 距離による圧力降下の割合は 2 次空気供給地点 までの区間がやや減少が少なく，2 次空気供給
区間の方が減少傾向が大きい.

（5）供給水量が一定で, 元空気量 $Q_{m a}$ と 2 次空気量 $Q$ sa の合計量が送られるような供給条件の場合で は元空気量が異なるため元空気供給地点では元 空気量の差に対応した圧力差が生じるが，2次 空気の供給地点より後の区間の圧力降下量は total空気量が等しいため減少傾向は全く同様 な傾向となり圧力も同じ值となる.

（6） 2 次空気量を供給する場合のスラグ流の速度は 供給空気量によってその割合は異なるが，いず れの場合も 2 次空気を供給することにより供給 後の管内のスラグ速度は上昇し, 元空気量の 1.5 倍の 2 次空気量では約 3 倍の速度になって いる.このことは空気量を分割することで圧力 損失を軽減できると考えられる.

（7） 2 次空気量の大小によるスラグ速度を見ると 2 次空気量が多いほど速度の増加率は大きくなる. しかしスラグ流の初速度は元空気量で決まるの で, 元空気量による速度差はそのまま維持され, 2 次空気によるスラグ速度の増加率は変わらな い. また, 2 次空気の供給前の地点のスラグ流 の速度は一定なので 2 次空気の供給による影響 はほとんど受けないと考えられる。

（8）管路終端付近でのスラグ流の速度は元空気のみ でも 2 次空気を適当な量を供給した場合でも total空気量が等しければ途中の空気量の供給 位置や供給の仕方に関係なくスラグ流の速度は total空気量に支配されることが明かとなった。

（9）管内の単位長さ当たりの圧力損失はスラグ速度 の増加と共に増大する傾向にあるが，スラグ流 の速度が大きくなると圧力損失がやや減少する.

\section{参考文献}

1) 森川, 辻 : 空気輸送に対する数值実験, 日本機会学会 論文集(2部),43巻, 375合, pp4151 4167, 1997.

2) 辻, 関, 森川: 空気輸送の数值実験, 粉体工学会, Vol.20, No.5, pp270 279, 1993.

3) 宮田, 沈: 水平流における空気輸送の数值実験, 日本 機会工学会(B編), 52巻, 474合, pp491〜1002, 1986.

4) 岡山 : 水平管における空気を含んだ軟泥の流動,（第 2報），作業船204号, pp38〜 51, 1992.

5) 岡山, 鮎貝, 鈴木, 福本 : 水平管における空気混入軟 泥の流動特性（第2報）, 港湾技術研究所報告, Vol.31, No.3, pp97 126, 1992.

6) 西川, 橋本, 片山, 武居, 松前, 堀井: 混気圧送浚渫 泥輸送のシステムにおける液相スラグの流動現象-液相 スラグの生成・成長・崩壊-, 混相流, 7 巻, 4 号, pp335 343, 1993.

7)鈴木, 落合, 遠藤 : 混気圧送における液相スラグの生 成流動に関する研究, 土木学会海洋開発論文集, Vol.19, pp421〜426, 1999.

8) 鈴木, 落合, 遠藤: 混気圧送水平管における液相スラ グの流動特性に関する研究, 土木学会水工論文集, Vol.44, pp885〜890, 2000. 